\title{
Effect Of Vertical Irregularity On Fundamental Period AndStability Of Reinforced Concrete Building
}

\author{
Bereket Netsanet Bekele $^{\mathbf{1}}$ Wudenesh Honja Angelo ${ }^{2}$ \\ ${ }^{1}$ Lecturer, Department of Civil Engineering, Wolaita Sodo University, Ethiopia \\ Email: bekelebereket200@gmail.com \\ ${ }^{2}$ Lecturer, Department of Civil Engineering, Wolaita Sodo University, Ethiopia \\ Email:wudehonja@yahoo.com
}

\begin{abstract}
Now a day, many building have not regular configuration both in plan and in elevation due to different functional and aesthetic requirements. Hence, the evaluation of the seismic behavior of reinforced concrete building with plan and elevation irregularity is required. In this study the evaluation of the effect setback irregularity on fundamental and stability of reinforced concrete. The standards used for analysis of base case building and vertical irregular building using response spectrum analysis (RSA) method are adopted according to the provision of ES EN 1998-1:2015. The evaluation of fundamental period and stability based on the value of sensitive inter-story drift were assessed in detail using seven different building. Story eight and Story twelve reinforced concrete building with different setback irregularity were selected and their responses werecompared with the ones of a corresponding base case was done using ETABS 2016.1.0 software. The setback of building is formed by the abrupt reduction in different floor area along the height of the building. The fundamental period and stability of setback buildings was found to be significantly different from the base case building, according to the findings of this study. It was discovered that the fundamental period of rigidity irregular buildings is longer than that of equivalent regular buildings. The fundamental period of a setback structure is shorter than that of a comparable regular structure. The findings reveal that the seismic response variation of setback building from the base case is dependent not only on the size of the irregularity, but also on the placement of the irregularity.
\end{abstract}

Key words: Setback, fundamental period, stability, irregularity

\section{INTRODUCTION}

Recently, many buildings have been built with irregular vertically and plans due to their aesthetic value and city recommendations. Although it is impossible to completely eliminate irregularities in multi-story buildings, the behavior of these buildings during earthquakes must be carefully assessed and evaluated. Adequate precautions can be taken. In today's world, designing an earthquake-resistant structureis a not easy. As a result, it is necessary to conduct a study of the seismic behavior ofreinforced concrete buildings with vertical and plan irregularities in order to have a good understanding. (All-Ali AAK, 1998). Recently, many buildings, due to their pleasing appearance and city recommendations, have become irregular in both elevation and plan, making them exposed to devastating earthquakes. (Das, 2003). Setback buildings have staggered sudden reductions in floor area along the building's height, resulting in a decrease in mass, strength, and stiffness. The dynamic features of these structures are determined by differences in stiffness and mass as a function of height. (K, 2014).Considering this fact, the present study highlighted the common irregularities and its effect on reinforced concrete building response. [1]

\subsection{Objective}

$\checkmark$ To study the effect of vertical irregularity on fundamental period of reinforcedconcrete buildings compared to base case.

$\checkmark \quad$ To study the effect of setback on stability reinforced concrete building.

$\checkmark \quad$ To compare the seismic response of setback building with the regular building.

$\checkmark \quad$ The scope of this study only RC buildings are considered and consider only verticalirregularity. 


\section{REVIEW OF LITERATUREE}

(Humar, 1977): Using one ground motion data, researchers investigated the seismic response of multistory steel building frames with and without setback irregularities. According to an analytical study, the storey drift in building frames with setbacks is bigger in the upper portion of the setback and smaller at the lower portion. Furthermore, as compared to their ordinary counterparts, the drift of building frameswith setbacks was shown to be smaller.

(Wong, 1994): When associating the seismic response of structures with setback irregularity to the static code approach, it was discovered that buildings with setback irregularity had greater modal masses, resulting in a different seismic load distribution.

(Fragiadakis, 2005): The seismic response of building systems with a staggered vertical distribution of strength and stiffness was determined. After conducting the analytical analysis, it was determined that the structure's seismic performance was relay on the type and location of irregularities, as well as the degree of seismic excitation.

(Poonam, 2012): The numerical research revealed that any storey, particularly the first, cannot be softer or weaker than the story above or below it. Irregularities in massdistribution also contribute to the buildings' greater responsiveness. If irregularities are necessary, they must be given through proper and comprehensive analysis and design processes.

The purpose of this study is to look into the effect of setback on fundamental period and stability of reinforced concrete buildings that had setbacks and stiffness irregularities. The criteria and requirements for applying response spectrum analysis (RSA) to analyze base case and vertical irregular buildings are based on the provisions of ES EN 1998-1:2015. seven different buildings were used to compare the fundamental period and stability of the building.[2]

As a result, vertical abnormalities have a significant impact on the seismic performance of structures. The dynamic characteristics of these buildings differ from conventional buildings due to height-based changes in stiffness and mass. The method of analysis to be employed is the most significant point when a structure has irregularities in mass, stiffness, strength, or vertical geometric irregularity. Building analysis methods are recommended in many nations' existing building design codes based on this. Linear static, linear dynamic, nonlinear static, and nonlinear dynamic analysis are the four types of analysis methods. The first two are suitable among various methods of analysis.[3]

Setback in buildings introduces staggered abrupt reductions in floor area along the height of the building. setback building form is becoming increasingly popular in modern multi-storey building construction mainly because of its functional and aesthetic architecture. In particular, such a setback form provides for adequate daylight and ventilation for the lower storey in an urban locality with closely spaced tall buildings. This setback affects the mass, strength, stiffness, center of mass and center of stiffness of setback building. Dynamic characteristics of such buildings differ from the regular building due to changes in geometrical and structural property. Design codes are not clear about the definition of building height for computation of fundamental period. The bay wise variation of height in setback building makes it difficult to compute natural period of such buildings. With this background it is foundessential to study the effect of setbacks on the fundamental period and stability of buildings. [4][5] 


\section{METHODOLOGY}

There is a methodology that was designed to attain the objectives of this study work in the steps necessary to complete it. The following is a list of the methods that was employed.

1. A review of the literature by several researchers.

2. The types of reinforced concrete buildings that will be employed in the analysis and modeling.

3. ETABS 2016 was used to model the selected buildings. Version 1.0 of the software.

4. The criteria and requirements for applying response spectrum analysis (RSA) to analyze base case and vertical irregular buildings are based on the provisions of ES EN 1998-1:2015.

5. seven distinct buildings were used to analyze the comparison of fundamental periodand elastic demand of building (story displacement, story drift, story shear, and base shear).

Equivalent static analysis is not used in this study since the building to be used is notregular and hence does not meet the ES EN (1998-1]., 2015) criteria to use this method. As a result, linear dynamic analysis (response spectrum analysis) is utilized to assess elastic reactions. The research is based on a threedimensional RC structurewith stiffness and uneven setbacks. Special concrete moment resisting 3D frames with stiffness and setback irregularity are investigated in order to determine seismic response of building structures. For the investigation, various building geometries were used. Buildings of eight and twelve stories are being explored. Because the buildings are symmetrical in plan, torsion isn't a factor; all floors are presumed to be rigid. Setback abnormalities is introduced at various points along the building's height. There are seven different building geometries, two regular and five irregular reinforced concrete building is considered. Presents the elevation of all seven different geometries of building[6][7]. Reinforced concrete building with setback are named as regular story eight (RS8.), regular story twelve (RSS12.), irregular story eight with setback at story three (IRR.S8.SB3), irregular story eight building with setback at story seven (IRR.S8.SB7), irregular story twelve with setback at story two (IRR.S12.SB2), irregular story twelve with setback at story seven (IRR.S12.SB7) and irregular story twelve with setback at story nine (IRR.S12.SB9) depending on the location setback introduced.

\section{ANALYSIS}

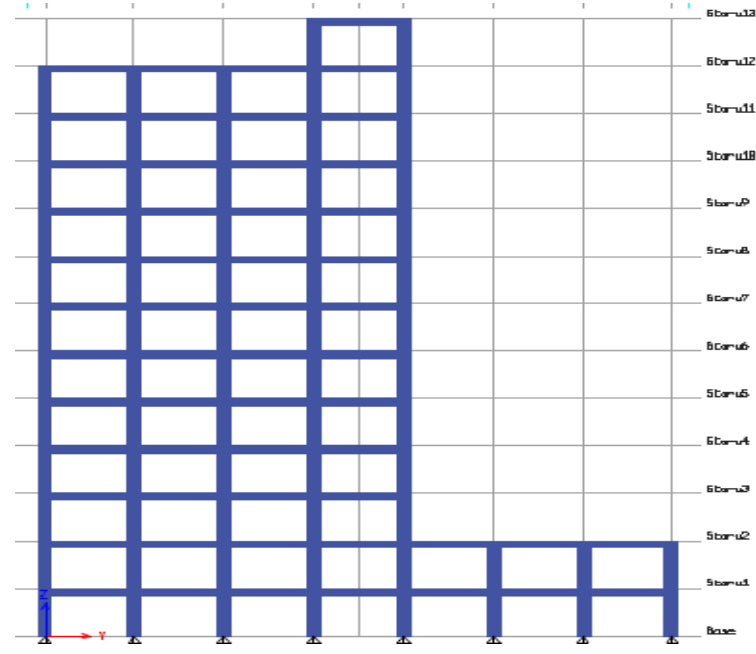

Figure 1: Story 12 Building Frame with Setback at Story 2 (IRR.S12. SB2) 


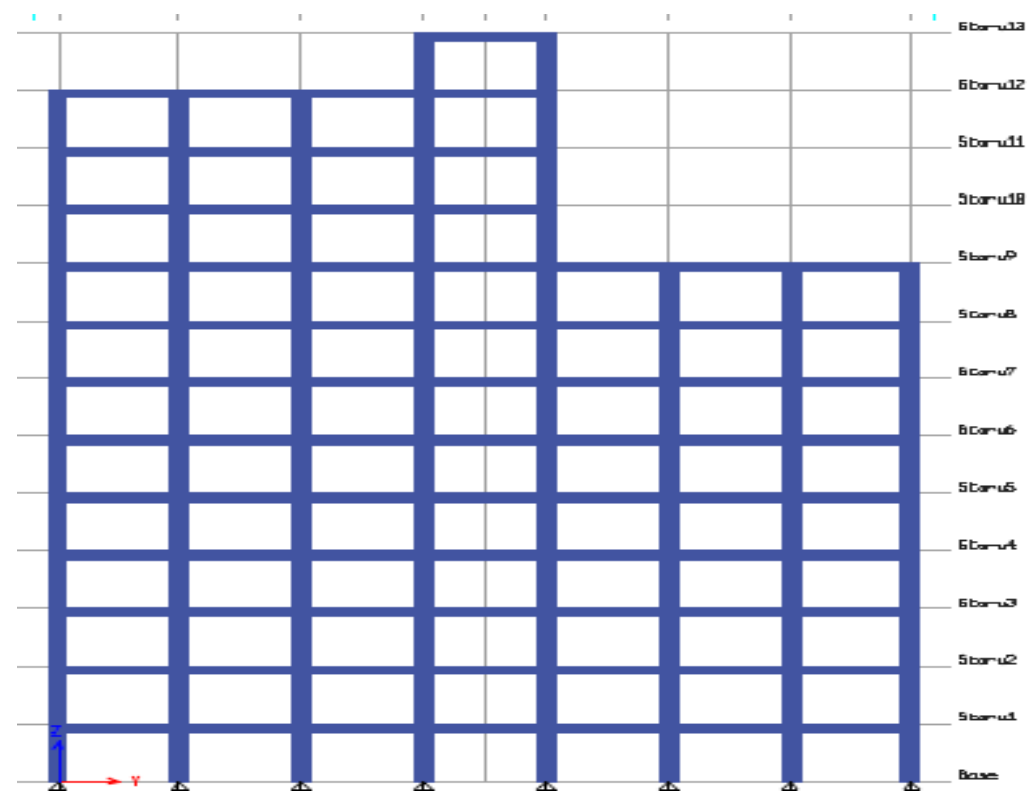

Figure 2: Story 12 Building Frame with Setback at Story 9 (IRR.S12. SB3)

All of the building structures are analyzed according to EBCS EN ([1998-1], ES EN, 2015)

ETABS software is used for the analysis

Table 1: The Material and The Parameter Used in This Analysis

\begin{tabular}{|c|c|c|c|}
\hline \multicolumn{2}{|l|}{ Peak ground acceleration ag } & \multicolumn{2}{|l|}{$0.1 \mathrm{~g}$} \\
\hline \multicolumn{2}{|l|}{ Concrete } & \multicolumn{2}{|l|}{ C-30 } \\
\hline \multicolumn{2}{|l|}{ Rebar } & \multicolumn{2}{|l|}{ S-500 } \\
\hline \multicolumn{2}{|l|}{ Modulus of elasticity of concrete } & \multicolumn{2}{|l|}{$33 \mathrm{GPa}$} \\
\hline \multicolumn{2}{|l|}{ Modulus of elasticity of steel } & \multicolumn{2}{|l|}{$200 \mathrm{GPa}$} \\
\hline \multicolumn{2}{|l|}{ Importance factor } & \multicolumn{2}{|l|}{1} \\
\hline \multicolumn{2}{|l|}{ Earthquake zone } & \multicolumn{2}{|l|}{ Zone 2} \\
\hline \multicolumn{2}{|l|}{ Damping ratio } & \multicolumn{2}{|l|}{$5 \%$} \\
\hline \multicolumn{2}{|l|}{ Soil class } & \multicolumn{2}{|l|}{$\mathrm{C}$} \\
\hline \multicolumn{2}{|l|}{ Building type } & \multicolumn{2}{|c|}{ Special moment resisting $\mathrm{RC}$ frame } \\
\hline Number of story building & \multicolumn{2}{|c|}{ Beam dimension $(\mathrm{mm})$} & Column dimension $(\mathrm{mm})$ \\
\hline 8 & \multicolumn{2}{|l|}{$300 \times 400$} & $400 \times 400$ \\
\hline 12 & \multicolumn{2}{|l|}{$350 \times 450$} & $600 \times 600$ \\
\hline
\end{tabular}




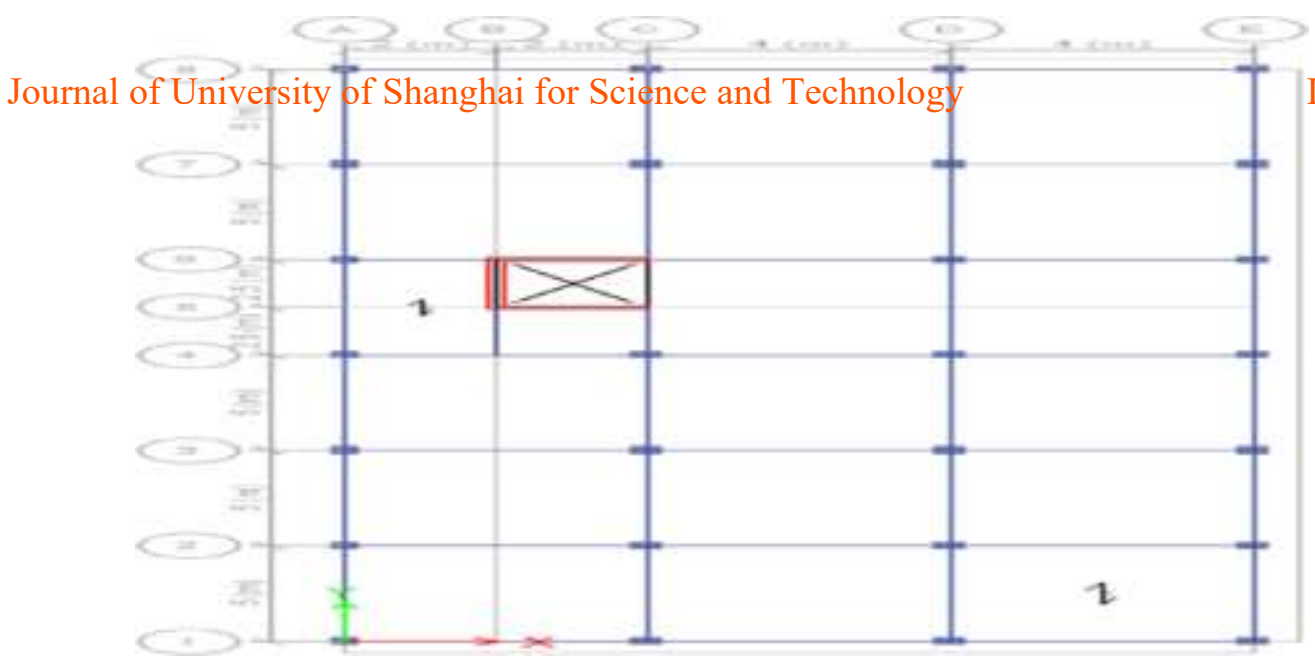

Figure 3: Plane of Story Eight Building.

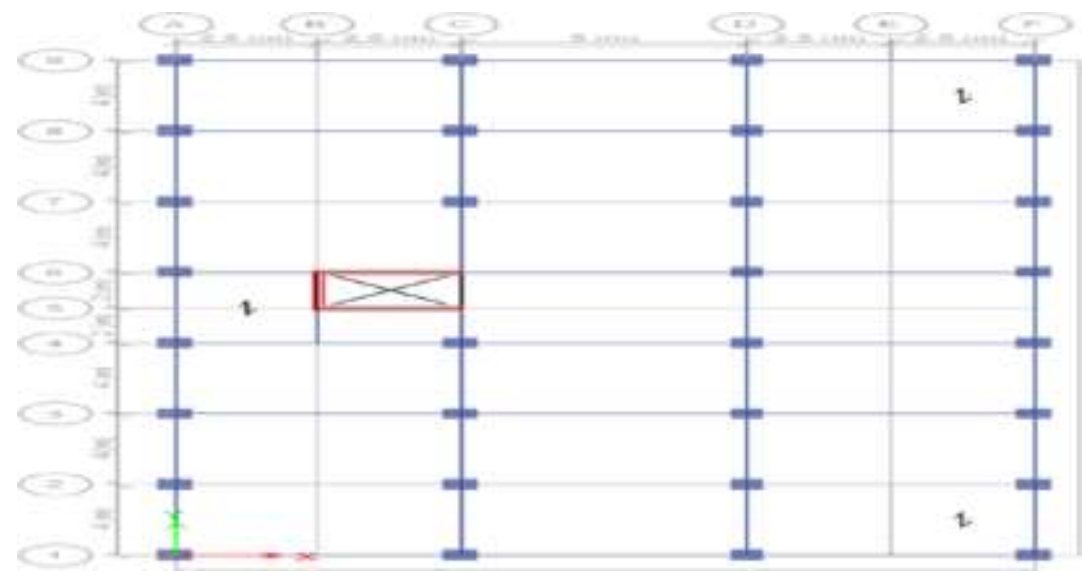

Figure 4: Plane of Story Twelve Building

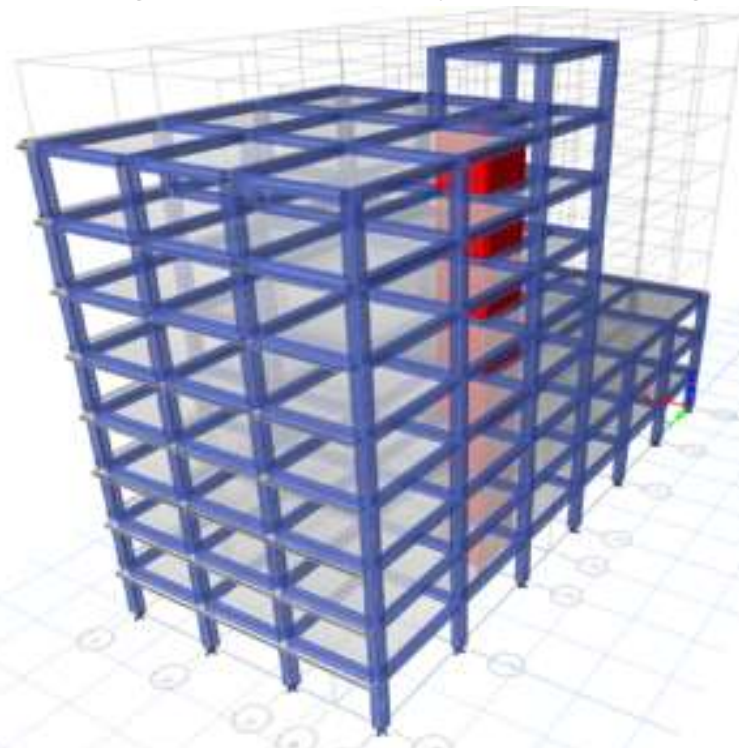

Figure 4: 3D Of Story Eight-Setback Building 


\section{RESULT AND DISCUSSION}

In modern buildings, structural imperfections are a typical element, and they are favored primarily for functional and aesthetic reasons. When irregularities exist in abuilding system, the seismic reaction of the structure varies.[8][9]

Check the inter-story drift sensitivity coefficient, $\theta \leq 0.1$.

$\varlimsup^{\text {Ptotdr }} £ 0.1$

$\mathrm{V}_{\text {toth }}$

Where:

$\mathrm{H}$ is the inter storey height.

$\mathrm{Dr}_{\mathrm{r}}$ is the design inter storey drift, evaluated as the difference of the average lateral

Displacements ds at the top and bottom of the storey under consideration.

Ptot is the total gravity load at and above the storey considered in the seismicdesign situation; and

V tot is the total seismic storey shear

$\checkmark \quad$ If the interstory drift sensitivity, coefficient पess than 0.1 the frame is nonswayunless sway.

$\checkmark \quad$ If the interstory drift sensitivity coefficient पess than 0.3 the frame is stable unlessunstable.

Table.2: Stability Checking for Story Eight Building

\begin{tabular}{|c|c|c|c|c|c|c|c|}
\hline & & & & & \multicolumn{2}{|c|}{ stability checking } \\
\hline $\begin{array}{l}\text { Story } \\
\text { No. }\end{array}$ & $\mathrm{P}(\mathrm{kN})$ & $\mathrm{V}(\mathrm{kN})$ & $\begin{array}{l}\text { story } \\
\text { drift(m) }\end{array}$ & height $(m)$ & $\sqsubset$ & & \\
\hline Story8 & 10761.52 & 859.7841 & 0.005151 & 3 & 0.021491 & stable & Non sway \\
\hline Story7 & 19947.364 & 1634.1565 & 0.005887 & 3 & 0.023953 & stable & Non sway \\
\hline Story6 & 29133.209 & 2303.673 & 0.006243 & 3 & 0.026317 & stable & Non sway \\
\hline Story5 & 38319.054 & 2867.6896 & 0.006524 & 3 & 0.029059 & stable & Non sway \\
\hline Story4 & 47504.898 & 3325.3229 & 0.006665 & 3 & 0.031738 & stable & Non sway \\
\hline Story3 & 56690.743 & 3675.5061 & 0.006592 & 3 & 0.033892 & stable & Non sway \\
\hline Story2 & 65876.587 & 3917.1485 & 0.007596 & 3 & 0.042582 & stable & Non sway \\
\hline g- story & 75062.432 & 4050.2257 & 0.011176 & 3 & 0.069041 & stable & Non sway \\
\hline
\end{tabular}


Table 3: Stability Checking for Story Eight Building

\begin{tabular}{|c|c|c|c|c|c|c|c|}
\hline & & & & & & stabilit & ecking \\
\hline $\begin{array}{l}\text { Story } \\
\text { No. }\end{array}$ & $\mathrm{P}(\mathrm{kN})$ & $\mathrm{V}(\mathrm{kN})$ & $\begin{array}{l}\text { story } \\
\text { drift(m) }\end{array}$ & height $(m)$ & $\sqsubset$ & & \\
\hline Story 12 & 5002.7358 & 1257.72 & 0.00299 & 3 & 0.00396 & stable & Non sway \\
\hline Story11 & 9329.5854 & 1997.72 & 0.003503 & 3 & 0.00545 & stable & Non sway \\
\hline Story 10 & 13656.435 & 2434.8 & 0.003893 & 3 & 0.00728 & stable & Non sway \\
\hline Story9 & 17983.285 & 2703.88 & 0.004234 & 3 & 0.00939 & stable & Non sway \\
\hline Story8 & 22310.134 & 2893.04 & 0.004526 & 3 & 0.01163 & stable & Non sway \\
\hline Story7 & 26636.984 & 3068.33 & 0.004757 & 3 & 0.01377 & stable & Non sway \\
\hline Story6 & 30963.834 & 3283.97 & 0.004921 & 3 & 0.01547 & stable & Non sway \\
\hline Story5 & 35290.683 & 3563.18 & 0.004991 & 3 & 0.01648 & stable & Non sway \\
\hline Story4 & 39617.533 & 3893.7 & 0.004911 & 3 & 0.01666 & stable & Non sway \\
\hline Story3 & 43944.383 & 4237.39 & 0.004564 & 3 & 0.01578 & stable & Non sway \\
\hline Story2 & 48271.232 & 4527.42 & 0.003901 & 3 & 0.01386 & stable & Non sway \\
\hline Story1 & 52598.082 & 4695.2 & 0.00414 & 3 & 0.01546 & stable & Non sway \\
\hline
\end{tabular}

The remaining value of the inter-story drift sensitivity coefficient is in raw data.

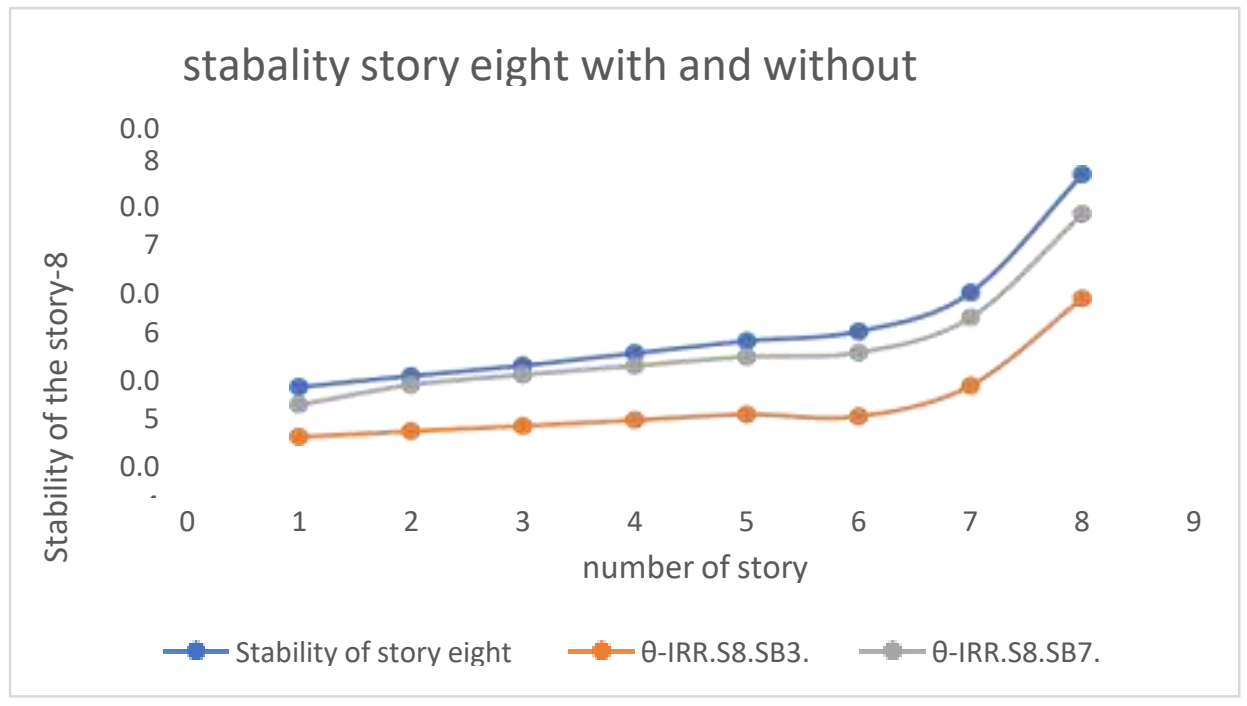

Figure 5: Change in Stability with Setback Irregularity For 8-Story Building stability of story twelev with and without setback

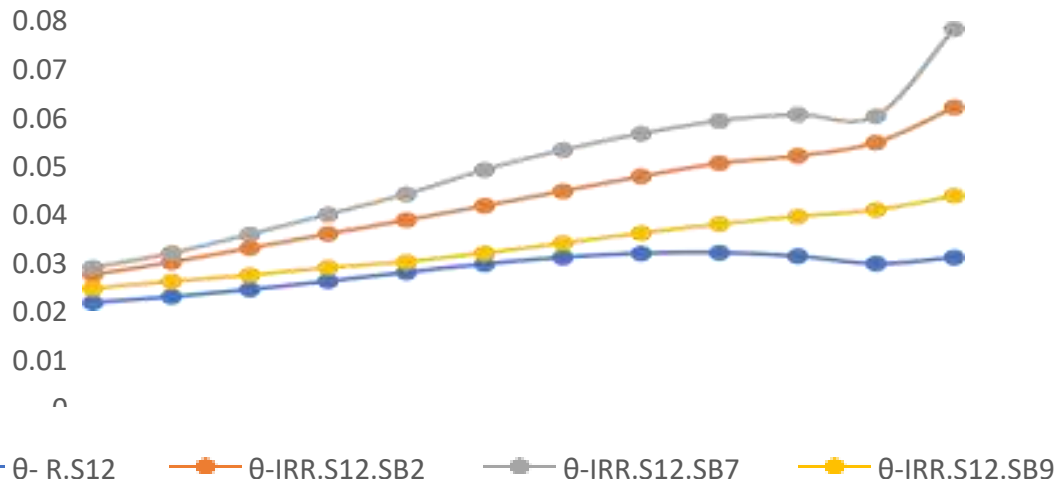

Figure 6: Change in Stability with Setback Irregularity of 12-Story Building 
The determination of inter-story drift sensitivity coefficient is an important stage in seismic design and analysis of building structures since it represents the structure's worldwide seismic demands. The stability of a building is mostly determined by factors such as mass, stiffness, seismic excitation, storey height, and number of storeys. The stability is influenced by structural irregularity and fundamental features. The goal of this study is to see how setback irregularity affect stability. For setback story 8 and story 12 buildings, the variation of inter-story drift sensitivity coefficientis examined in relation to the base condition. In comparison to the base case, the inter-story drift sensitivity coefficient for story 8 building with setback irregularity at story 3 decreases by approximately 56.1 percent, and at story 7 decreases by approximately 8.41 percent.In comparison to the base case, the inter-story drift sensitivity coefficient for story 12 building with setback irregularity at story 2 increases by about 222.4 percent, at story7 decreases by about 174.14 percent, and at story 9 decreases by about 36.63 percent.[10]

Generally, the fundamental period decreases with setback irregularity for stories 8 andincreases with setback for story 12 building with respect to base case.The determination of fundamental period of vibration is an important stage in seismic design and analysis of building structures since it represents the structure's worldwide seismic demands. The period of a building is mostly determined by factors such as mass, stiffness, seismic excitation, storey height, and number of storeys.[12] The basic time period is influenced by structural irregularity and fundamental features. The goal of this research is to see how setback irregularity affect fundamental naturalperiod variation. For setback story 8 and story 12 buildings, the variation of essential natural period is examined in relation to the base condition. In comparison to the basecase, the fundamental natural period for story 8 building with setback irregularity at story 3 decreases by approximately 40.434 percent, and at story 7 decreases by approximately 11.562 percent.In comparison to the base case, the fundamental natural period for story 12 building with setback irregularity at story 2 decreases by about 6.46 percent, at story 7 decreases by about 8.591 percent, and at story 9 decreases by about 6.426 percent.Generally, the fundamental period decreases with setback irregularity for both stories 8 and story 12 building with respect to base case.[11]

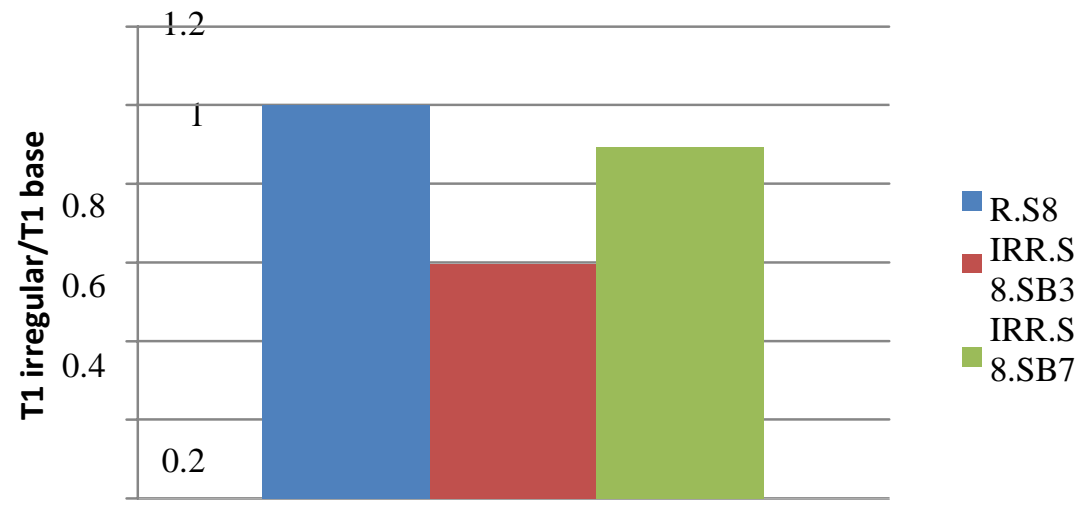

0

setback at different story

Figure 7: Change in Fundamental Period with Setback Irregularity For 8StoryBuilding 


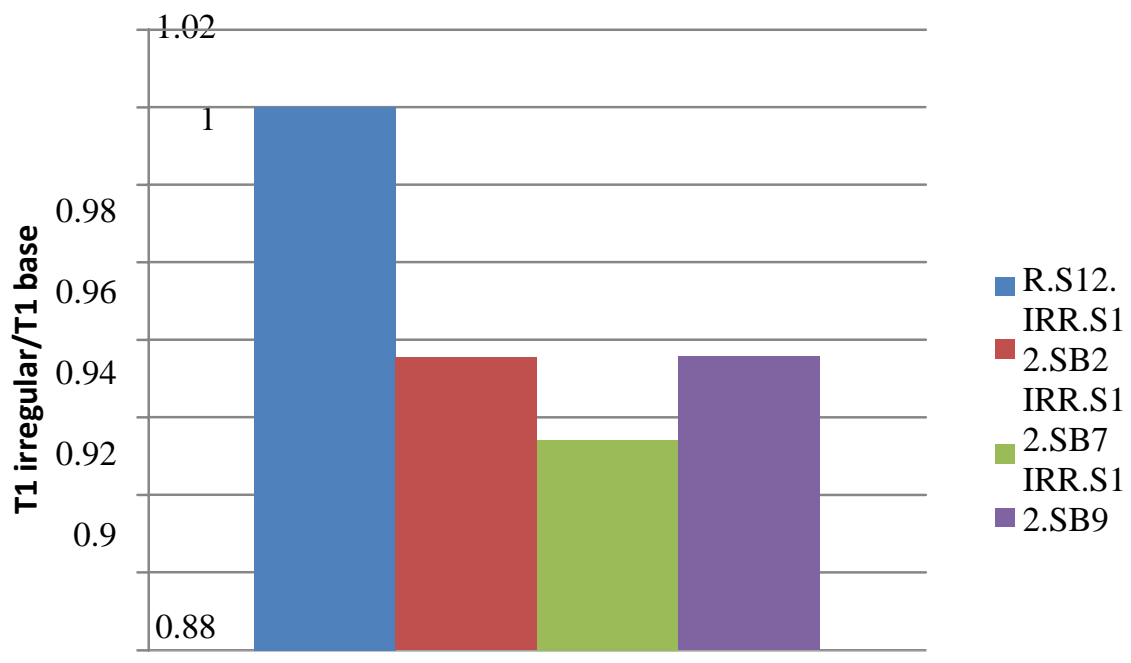

0.86

setback at different story

Figure 8: Change in Fundamental Period with Setback Irregularity For 12StoryBuilding

\section{CONCLUSION}

Fundamental period of all the selected building models was estimated as per modal Analysis. The results were critically analyzed and presented in this study. Also, the Based on the work presented in this study following point-wise conclusions can be drawn:

The fundamental period decreases with setback irregularity for both eight story and twelve-story building with respect to base case. The study show that the fundamental natural period of the setback building is varying even the maximum height of the building is the same with base case building. Therefore, the study shows that the fundamental natural period not only depends on height of the building.

The buildings with same maximum height and same maximum width may have different period depending on the amount of irregularity present in the setback buildings. This variation of the fundamental periods due to variation in irregularity is found to be more for taller buildings and comparatively less for shorter buildings.

The goal of this study is to see how setback irregularity affect stability. For setback story 8 and story 12 buildings, the variation of inter-story drift sensitivity coefficientis examined in relation to the base condition.

In comparison to the base case, the inter-story drift sensitivity coefficient for story 8 building with setback irregularity at story 3 increases the non-sway property of the building compared with the base condition and introducing the setback at story-7 increases the non-sway property of the building.

In case of story 12 building introducing setback at different level of building decreases the property of nonsway and leads to sway. Also, the property of stabilitydecreases and leads to unstable when introducing setback at different level of building compared with base condition. When the height of building increase with setback the unstability of the building increases.

\section{ACKNOWLEDGMENT}

We would like to thank wolaita sodo university for the motivating us to work research. Special thanks also support the respondents fordedicating their time and sharing their ideas and concepts compassionately. 


\section{References}

[1] [1998-1], ES EN. (2015). Design of Structures for Earthquake Resistance. Ethiopian Building Code Standard-8, part-1.

[2] All-Ali AAK, K. H. (1998). "Effect of Vertical Irregularities on Seismic. Blume earthquakeengineering center, Stanford, 130.

[3] Das, S. a. (2003). "Seismic Design Aspects of Vertically Irregular". Earthquake Spectra, 19(3), pp. $455-477$.

[4] Dr.A.Paulmakesh, Gizachew Markos Makebo October 2021The Effect of Glass Fiber on Concrete and Reinforced Concrete Beam under Elevated Temperature, Journal of Physics Conference Series 2040(1):012027, DOI:10.1088/1742-6596/2040/1/012027

[5] Fragiadakis, M. V. (2005). Evaluation of the influence of vertical Stiffness irregularities on the seismic response of a 9-story steelframell. In Proceedings of the 4th European workshop on the seismic behavior of irregular and complex structures, CD ROM. Thessaloniki.

[6] Dr.A. Paulmakesh, Dec 2021, "Analysis of uncertainty in a construction project" YMER journal, Vol 20,Issue 12, pg.no 324-332.

[7] Humar, J. a. (1977). Earthquake Response of Steel-Framed Multistory Buildings with Set- Backs. Earthquake Engineering \& Structural Dynamics,, 5(1), pp.15-39.

[8] Dr.A. Paulmakesh, Yimam Mohammed Yimer April 2021, "Implementation of Project Management for Strategy Realisation” Journal of University shanghai for Science and Technology, Volume 23, Issue 10,Pg.No 887-892

[9] K, M. V. (2014). "Seismic Behaviour of Setback Buildings". international journal of innovative research in science, engineering and technology,, 3, pp.235-241.

[10] Poonam, K. A. (2012). Study of Response of Structural Irregular Building Frames to Seismic Excitations. International Journal of Civil, Structural, Environmental and Infrastructure Engineering Research and Development (IJCSEIERD), 2(2), 25-31.

[11] Dr.A. Paulmakesh, Gizachew Markos Makebo April 2021, "Management of contracts for Durable structures" Innovations, Number 64,Pg 1044-1054

[12] Wong, C. a. (1994). Seismic Loading for Buildings with Setbacks. Canadian Journal of Civil Engineering, 21(5), pp. 863- 871. 